\title{
Population Genetic Structures of Puccinia striiformis in Ningxia and Gansu Provinces of China
}

Junmin Liang, Qiong Wan, Yong Luo, and Zhanhong Ma, Department of Plant Pathology, China Agricultural University, Beijing 100193, P. R. China

\begin{abstract}
Liang, J.-M., Wan, Q., Luo, Y., and Ma, Z.-H. 2013. Population genetic structures of Puccinia striiformis in Ningxia and Gansu provinces of China. Plant Dis. 97:501-509.

Wheat stripe rust, caused by the fungal pathogen Puccinia striiformis $\mathrm{f}$. sp. tritici, is one of the most destructive plant diseases in China. Gansu and Ningxia Provinces are considered to be the key areas for oversummering of this pathogen in China. In this study, 283 P. striiformis $\mathrm{f}$. sp. tritici isolates were collected in these two provinces. Amplified fragment length polymorphism (AFLP) was used to analyze the population genetics and to infer the chance of population exchanges between different geographic locations and seasons. The genotypic diversity of the Gansu population (0.514) was slightly higher than that of

the Ningxia population (0.489). The occurrence of frequent population exchanges between these two regions was observed, showing that 40 AFLP genotypes were shared by the populations of the two provinces. Gene flow between these two regions in autumn and spring subpopulations was also detected. The genotype distribution in three populations of Ningxia from opposite sides of the Liupan Mountains revealed possible significant effects of the mountains on limiting gene flow and population exchange. Phylogenetic analysis confirmed the possibility of recombination in some of the studied subpopulations in both provinces.
\end{abstract}

Wheat stripe rust, caused by Puccinia striiformis f. sp. tritici, is a destructive wheat disease throughout the world $(12,20,21,28)$. China is one of the largest wheat-producing and -consuming countries in the world, where stripe rust usually causes various levels of yield loss (22). During epidemics in 1950, 1964, 1990, and 2002, stripe rust caused yield losses up to $6.0,3.0,1.8$, and 1.3 million metric tons, respectively $(22,23)$. In China, wheat stripe rust exists as a unique system, in which 15 epidemic regions are classified (29) according to cropping system, geographic and climatic conditions, pathogen life-cycle features, roles in interregional epidemics within the country, and factors influencing long-distance disease spread and pathogen dispersal.

The major pathogen over-summering regions in China cover the mountainous areas in southern and eastern Gansu Province, southern Ningxia Province, northwestern Sichuan Province, and southern Qinghai Province (29). It is important to understand the relationships between pathogen populations in these regions, in terms of possible gene flow, population exchange, dispersal pathways, and factors involved in geographic isolation. Among the pathogen over-summering regions, the areas of southern (Longnan) and eastern (Longdong) Gansu Province have been intensively studied (11). Because wheat is planted at various elevations in the mountains of this region, the over-summered populations from volunteer plants at high elevations can shift to lower ones and either overwinter and complete their life cycle there or disseminate from the area to serve as exogenous inoculum for epidemics in other regions (29). Due to the planting of many wheat cultivars with different agronomic characteristics and genetic backgrounds and the completion of the pathogen life cycle in this area, this region is consid-

Corresponding authors: Y. Luo, E-mail: ygluo@ucanr.edu;

and Z.Ma, E-mail: mazh@cau.edu.cn

J. Liang and Q. Wan contributed equally to this research.

Current address of Y. Luo: University of California, Kearney Agricultural Center, Parlier 93648.

Accepted for publication 30 October 2012.

http://dx.doi.org/10.1094/PDIS-01-12-0072-RE

(C) 2013 The American Phytopathological Society ered to be the key area where new $P$. striiformis f. sp. tritici races in China are initiated $(11,22,29)$. The occurrence of recombination $(6,13)$ in the populations and possible gene flow from this region to adjacent Qinghai (14) have been inferred.

Ningxia Province is on the eastern border of Gansu (Fig. 1). Both winter and spring wheat are grown in different districts, with divergent topographic, climatic, and cultural systems. The Liupan Mountains, crossing southern Ningxia Province from north to south and with an average altitude of 3,000 $\mathrm{m}$ above sea level (asl), are considered to be one of the pathogen over-summering regions (29). However, information is lacking regarding the pathogen population genetics in this region. It is essential to understand the relationships of pathogen populations between Gansu and Ningxia Provinces. Information on genetic and genotypic diversities, seasonal population changes, and possibility of recombination and occurrence of gene flow could be useful to draw conclusions on the pathogen's life cycle and reproduction related to interregional epidemics.

There have been a number of studies regarding $P$. striiformis $\mathrm{f}$. sp. tritici population genetics in different geographical regions in China. The amplified fragment length polymorphism (AFLP) method was used (10) and proved useful in the phylogenetics of $P$. striiformis f. sp. tritici. Mboup et al. (15) studied the genetic structure of P. striiformis f. sp. tritici in Tianshui County, Gansu Province, China. They concluded that population genetic structure was not dependent on the elevation of the mountains. Duan et al. (6) demonstrated possible genetic recombination of the studied populations. Liu et al. (13) found that genetic recombination may exist in Gansu Province but not in Yunnan Province. Lu et al. (14) used simple sequence repeat (SSR) markers and concluded that $P$. striiformis f. sp. tritici inoculum in Qinghai possibly came from both Longnan and Linxia of Gansu but principally from Longnan in the spring. Wang et al. (23) found that the genetic diversity of P. striiformis $\mathrm{f}$. sp. tritici populations from northwest Sichuan Province, a pathogen over-summering region, and Sichuan Basin was much higher than the diversity of populations from other areas of Sichuan.

In this study, isolates of $P$. striiformis f. sp. tritici were collected from different geographic locations at various elevations in Gansu and Ningxia Provinces in different seasons during 2 years. AFLP was used to evaluate the samples. The objectives of this study were to (i) analyze the genetic and genotypic diversities among the sam- 
pled populations, (ii) determine the effects of the Liupan Mountains on the genetic structure of the Ningxia population, (iii) compare the genetic structure among seasonal populations in Gansu and Ningxia Provinces, and (iv) understand the possibility of recombination in the studied subpopulations.

\section{Materials and Methods}

Samples. During 2009 to 2010, diseased wheat leaves showing sporulation of $P$. striiformis $\mathrm{f}$. sp. tritici were collected from the major stripe rust epidemic areas of the two provinces (Fig. 1): four counties (26 sampling locations) of Ningxia Province and five counties (28 sampling locations) of Gansu Province in different seasons (Table 1). Isolates collected from the same county in the same season were considered as one subpopulation. At least five villages at least $10 \mathrm{~km}$ apart from each other were chosen in each county; 10 to 20 sampling sites in each village were randomly chosen, and approximately 30 infected leaves per sampling site were obtained. Leaf samples were collected from different wheat cultivars, if known. Isolates consisted of a single lesion per sampled leaf. During 2009 to 2010, 176 isolates of P. striiformis f. sp. tritici were obtained in Ningxia Province from plants in spring, volunteer seedlings in summer, and plants in autumn; and 107 isolates were obtained from Gansu Province in autumn and spring (Table 1).

Isolation and reproduction of isolates. A single pustule was used to obtain each isolate, on the assumption that each pustule was caused by a single urediniospore. To increase spores for DNA extraction, 10-day-old seedlings of universally susceptible 'Mingxian 169' were grown in a pot. The spores from the single pustule on a sampled leaf were picked and rubbed in a drop of water on the Mingxian 169 leaf surface. These inoculated seedlings were incubated at 8 to $10^{\circ} \mathrm{C}$ with dew for $24 \mathrm{~h}$ in darkness to promote infections, and transferred to an incubator at 17 and $14^{\circ} \mathrm{C}$ (day and night, respectively) with $14 \mathrm{~h}$ of light per day. After about 13 days, the spores were harvested from the lesions and then reinoculated as described above in order to further increase spores.
After these lesions developed, the spores were harvested from inoculated leaves, transferred into a $0.5-\mathrm{ml}$ Eppendorf tube, dried in desiccators at $4^{\circ} \mathrm{C}$ for 3 to 4 days, and stored at $-20^{\circ} \mathrm{C}$ for DNA extraction.

DNA extraction and AFLP. A modified cetyltrimethylammonium bromide procedure (10) was used to extract pathogen genomic DNA from fresh urediniospores (5 to $10 \mathrm{mg}$ per isolate). The DNA purity and its concentration of each isolate were determined using a spectrophotometer.

The following AFLP procedure, as described by Justesen et al. (10), was carried out. Of genomic DNA, 50 to $100 \mathrm{ng}$ was digested with PstI and MseI and ligated with $\mathrm{T}_{4}$-DNA ligase in a final volume of $25 \mu \mathrm{l}: 50$ to $100 \mathrm{ng}$ of DNA, $3 \mathrm{U}$ of MseI, $4 \mathrm{U}$ of PstI, 0.02 $\mu \mathrm{l}$ of $\mathrm{T}_{4}$-DNA ligase $(400 \mathrm{U} / \mu \mathrm{l}), 1.0 \mu \mathrm{l}$ of $P$ st I-adapter $(5 \mathrm{pmol} / \mu \mathrm{l})$, $1.0 \mu \mathrm{l}$ of $\mathrm{Mse}$ I-adapter $(50 \mathrm{pmol} / \mu \mathrm{l}), 2.5 \mu \mathrm{l}$ of $10 \times \mathrm{T}_{4}$-DNA ligase buffer ( $10 \mathrm{mM}$ ATP included), $0.5 \mu \mathrm{l}$ of $100 \times$ bovine serum albumen $(10 \mu \mathrm{g} / \mu \mathrm{l}), 2.0 \mu \mathrm{l}$ of $10 \times$ Taq Ex buffer (New England Biolabs Inc., Ipswich, MA) buffer, double-distilled (dd) $\mathrm{H}_{2} \mathrm{O}$ to attain a final volume of $25 \mu \mathrm{l}$. Digestion and ligation were performed in one tube at $37^{\circ} \mathrm{C}$ for $10 \mathrm{~h}$.

A preselective amplification was performed by using Pst $\mathrm{I} 0$ and MseIO (Table 2) in a volume of $20 \mu \mathrm{l}$ containing $2 \mu \mathrm{l}$ of digested

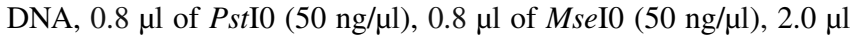
of 10x PCR buffer $\left(\mathrm{Mg}^{2+}\right.$ included $), 1.6 \mu \mathrm{l}$ of dNTP $(2.5$ $\mathrm{mmol} / \mathrm{liter}$ ), $0.2 \mu \mathrm{l}$ of $\mathrm{Taq}$ polymerase $(5 \mathrm{U} / \mu \mathrm{l})$, and $12.6 \mu \mathrm{l}$ of $\mathrm{ddH}_{2} \mathrm{O}$. The amplification was carried out under the following conditions: 30 cycles of $94^{\circ} \mathrm{C}$ for $30 \mathrm{~s}, 56^{\circ} \mathrm{C}$ for $30 \mathrm{~s}$, and $72^{\circ} \mathrm{C}$ for 60 s. A specific amplification was performed by using eight $P$. striiformis f. sp. tritici and Mse primer combinations (Table 2). Each primer combination with two selective nucleotides was determined based on a primer screening, and the Mse primer of each combination was modified by FAM or HEX fluorescence at the $5^{\prime}$ end. The selective reaction system was performed the same as the preselective reaction described above after the preselective production was diluted 30 times with $\mathrm{dd}_{2} \mathrm{O}$. The selective amplification was carried out under the following conditions: 13 cycles of $94^{\circ} \mathrm{C}$

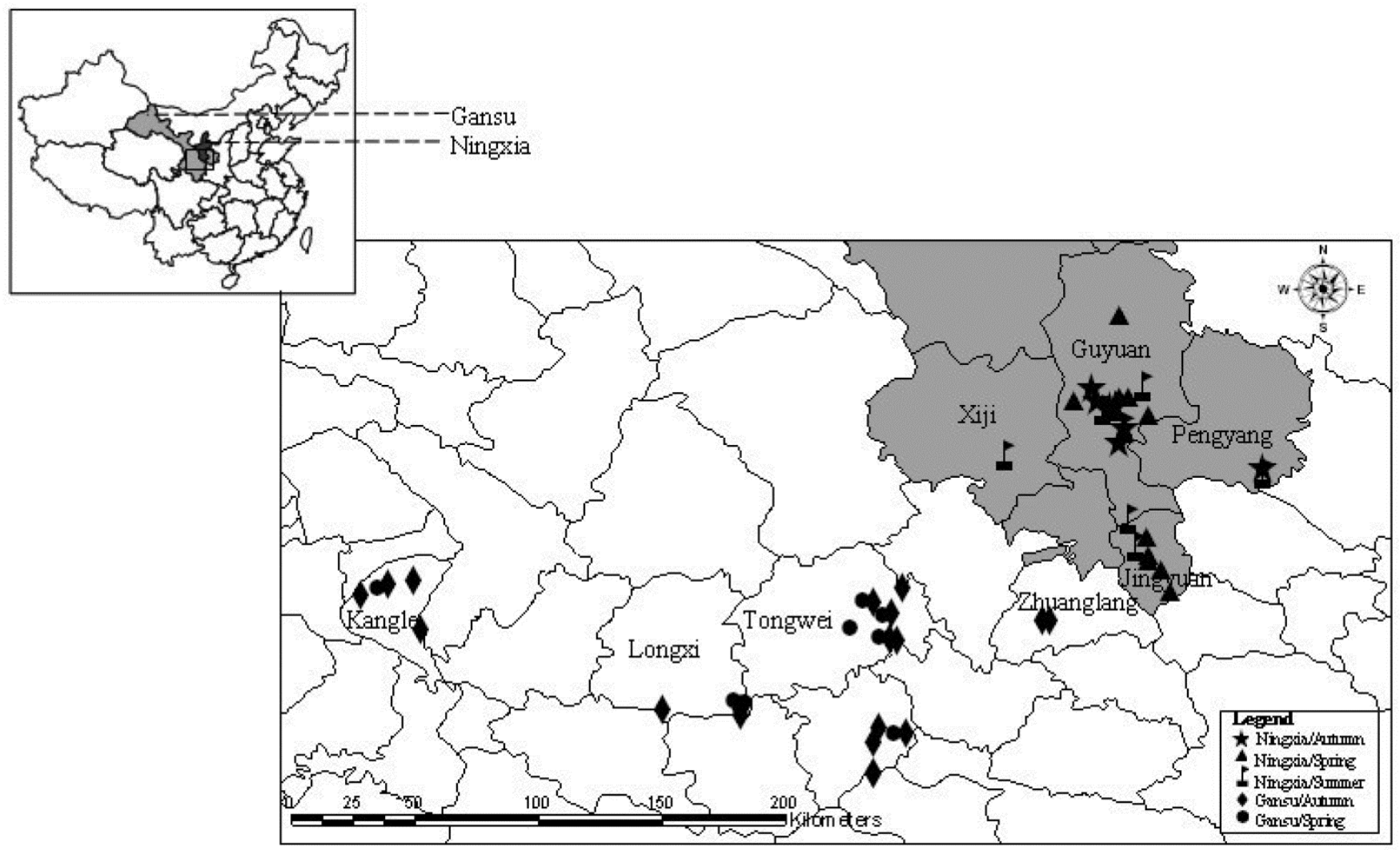

Fig. 1. Locations of four counties in Ningxia Province and five counties in Gansu Province of central China where 283 isolates of Puccinia striiformis were collected in this study. 
for $30 \mathrm{~s}, 65^{\circ} \mathrm{C}$ for $30 \mathrm{~s}$ with a $0.7^{\circ} \mathrm{C}$ decrement per cycle, and $72^{\circ} \mathrm{C}$ for $60 \mathrm{~s}$; and then 25 cycles of $94^{\circ} \mathrm{C}$ for $30 \mathrm{~s}, 56^{\circ} \mathrm{C}$ for $30 \mathrm{~s}$, and $72^{\circ} \mathrm{C}$ for $60 \mathrm{~s}$. All AFLP amplifications were performed in an Authorized Thermal Cycler (Eppendorf AG). Final polymerase chain reaction (PCR) products were separated and the amplified bands were visualized using ABI 3730XL automatic DNA sequencer (Applied Biosystems).

Data analysis. Polymorphic AFLP fragments with strong intensity were scored visually as 1 if present and 0 if absent. Each isolate was repeated two to three times to confirm the consistency of the polymorphic pattern. Additionally, 17 isolates were randomly selected from different subpopulations. Spores of each isolate were split into two subsamples to separately extract DNA. The primer pairs M12/P14 and M16/P12 were used to perform AFLP amplifications using the method described above. The AFLP fingerprints for the two subsamples of each isolate were compared and results confirmed the consistency of readable bands between the two subsamples for the selected isolates. In this study, only clearly repeatable bands of 0 to $500 \mathrm{bp}$ were included in the analysis that involved informative polymorphic markers shared by at least two individuals.

The numbers of AFLP genotypes within each province and among overall isolates were calculated by MULTILOCUS 1.3 (1), and then the genetic diversity within a population was assessed with POPGENE version 1.3.1 (27). Shannon's information index (I) and Nei's diversity index $(\mathrm{H})(16)$ were calculated. The gene diversity $(H t)$ of populations is the sum of average gene diversity among (Dst) and within $(H s)$ the populations. The genetic differentiation (Gst) among populations was calculated as Gst = $\mathrm{Dst} / \mathrm{Ht}$. Gene flow $(\mathrm{Nm})$ between any two studied populations was estimated as $N m=0.5(1-G s t) / G s t(18)$.

Table 1. Geographic origins of 283 isolates of Puccinia striiformis f. sp. tritici collected from various counties in Ningxia and Gansu provinces, China

\begin{tabular}{|c|c|c|c|c|}
\hline Province, season ${ }^{\mathrm{a}}$ & County (code) & Population code (number of isolates) ${ }^{b}$ & Latitude/longitude of sampling site & Elevation $(\mathbf{m})$ \\
\hline \multirow[t]{7}{*}{ Ningxia, autumn } & Guyuan (GY) & GYA (37) & $36^{\circ} 00^{\prime} \mathrm{N} / 106^{\circ} 14^{\prime} \mathrm{E}$ & 1,813 \\
\hline & & & $35^{\circ} 52^{\prime} \mathrm{N} / 106^{\circ} 15^{\prime} \mathrm{E}$ & 1,903 \\
\hline & & & $35^{\circ} 55^{\prime} \mathrm{N} / 106^{\circ} 16^{\prime} \mathrm{E}$ & 1,822 \\
\hline & & & $36^{\circ} 00^{\prime} \mathrm{N} / 106^{\circ} 13^{\prime} \mathrm{E}$ & 1,816 \\
\hline & & & $36^{\circ} 01^{\prime} \mathrm{N} / 106^{\circ} 10^{\prime} \mathrm{E}$ & 1,797 \\
\hline & & & $36^{\circ} 04^{\prime} \mathrm{N} / 106^{\circ} 09^{\prime} \mathrm{E}$ & 1,677 \\
\hline & Pengyang (PY) & PYA (7) & $35^{\circ} 46^{\prime} \mathrm{N} / 106^{\circ} 46^{\prime} \mathrm{E}$ & 1,515 \\
\hline \multirow[t]{9}{*}{ Ningxia, spring } & Jingyuan (JY) & JYB (17) & $35^{\circ} 24^{\prime} \mathrm{N} / 106^{\circ} 24^{\prime} \mathrm{E}$ & 1,768 \\
\hline & & & $35^{\circ} 27^{\prime} \mathrm{N} / 106^{\circ} 21^{\prime} \mathrm{E}$ & 1,828 \\
\hline & & & $35^{\circ} 31^{\prime} \mathrm{N} / 106^{\circ} 20^{\prime} \mathrm{E}$ & 1,980 \\
\hline & & & $35^{\circ} 19^{\prime} \mathrm{N} / 106^{\circ} 26^{\prime} \mathrm{E}$ & 1,742 \\
\hline & & & $35^{\circ} 26^{\prime} \mathrm{N} / 106^{\circ} 21^{\prime} \mathrm{E}$ & 1,907 \\
\hline & Guyuan (GY) & GYB (35) & $36^{\circ} 01^{\prime} \mathrm{N} / 106^{\circ} 05^{\prime} \mathrm{E}$ & 1,809 \\
\hline & & & $36^{\circ} 02^{\prime} \mathrm{N} / 106^{\circ} 15^{\prime} \mathrm{E}$ & 1,750 \\
\hline & & & $36^{\circ} 02^{\prime} \mathrm{N} / 106^{\circ} 17^{\prime} \mathrm{E}$ & 1,702 \\
\hline & & & $35^{\circ} 58^{\prime} \mathrm{N} / 106^{\circ} 21^{\prime} \mathrm{E}$ & 1,839 \\
\hline \multirow[t]{10}{*}{ Ningxia, summer } & Jingyuan (JY) & JYC (22) & $35^{\circ} 29^{\prime} \mathrm{N} / 106^{\circ} 19^{\prime} \mathrm{E}$ & 1,934 \\
\hline & & & $35^{\circ} 35^{\prime} \mathrm{N} / 106^{\circ} 17^{\prime} \mathrm{E}$ & 2,005 \\
\hline & & & $35^{\circ} 39^{\prime} \mathrm{N} / 106^{\circ} 15^{\prime} \mathrm{E}$ & 1,941 \\
\hline & & & $35^{\circ} 29^{\prime} \mathrm{N} / 106^{\circ} 19^{\prime} \mathrm{E}$ & 1,760 \\
\hline & Guyuan (GY) & GYC (37) & $35^{\circ} 55^{\prime} \mathrm{N} / 106^{\circ} 16^{\prime} \mathrm{E}$ & 1,746 \\
\hline & & & $35^{\circ} 59^{\prime} \mathrm{N} / 106^{\circ} 12^{\prime} \mathrm{E}$ & 1,875 \\
\hline & & & $36^{\circ} 04^{\prime} \mathrm{N} / 106^{\circ} 20^{\prime} \mathrm{E}$ & 1,951 \\
\hline & & & $36^{\circ} 00^{\prime} \mathrm{N} / 106^{\circ} 14^{\prime} \mathrm{E}$ & 1,813 \\
\hline & Xiji (XJ) & XJC (19) & $35^{\circ} 49^{\prime} \mathrm{N} / 105^{\circ} 50^{\prime} \mathrm{E}$ & 1,838 \\
\hline & Pengyang (PY) & PYC (2) & $35^{\circ} 45^{\prime} \mathrm{N} / 106^{\circ} 46^{\prime} \mathrm{E}$ & 1,614 \\
\hline \multirow{20}{*}{ Gansu, autumn } & Zhuanglang (ZL) & ZLA (8) & $35^{\circ} 12^{\prime} \mathrm{N} / 105^{\circ} 57^{\prime} \mathrm{E}$ & 1,870 \\
\hline & & & $35^{\circ} 12^{\prime} \mathrm{N} / 105^{\circ} 58^{\prime} \mathrm{E}$ & 1,865 \\
\hline & Tongwei (TW) & TWA (10) & $35^{\circ} 21^{\prime} \mathrm{N} / 105^{\circ} 27^{\prime} \mathrm{E}$ & 1,750 \\
\hline & & & $35^{\circ} 13^{\prime} \mathrm{N} / 105^{\circ} 43^{\prime} \mathrm{E}$ & 1,976 \\
\hline & & & $35^{\circ} 24^{\prime} \mathrm{N} / 105^{\circ} 40^{\prime} \mathrm{E}$ & 2,114 \\
\hline & & & $35^{\circ} 28^{\prime} \mathrm{N} / 105^{\circ} 34^{\prime} \mathrm{E}$ & 1,910 \\
\hline & & & $35^{\circ} 14^{\prime} \mathrm{N} / 105^{\circ} 40^{\prime} \mathrm{E}$ & 1,911 \\
\hline & Gangu (GG) & GGA (31) & $34^{\circ} 46^{\prime} \mathrm{N} / 105^{\circ} 21^{\prime} \mathrm{E}$ & 1,450 \\
\hline & & & $34^{\circ} 39^{\prime} \mathrm{N} / 105^{\circ} 21^{\prime} \mathrm{E}$ & 1,733 \\
\hline & & & $34^{\circ} 39^{\prime} \mathrm{N} / 105^{\circ} 21^{\prime} \mathrm{E}$ & 1,733 \\
\hline & & & $34^{\circ} 39^{\prime} \mathrm{N} / 105^{\circ} 21^{\prime} \mathrm{E}$ & 1,733 \\
\hline & & & $34^{\circ} 48^{\prime} \mathrm{N} / 105^{\circ} 22^{\prime} \mathrm{E}$ & 1,722 \\
\hline & & & $34^{\circ} 48^{\prime} \mathrm{N} / 105^{\circ} 27^{\prime} \mathrm{E}$ & 1,828 \\
\hline & Kangle (KL) & KLA (9) & $35^{\circ} 36^{\prime} \mathrm{N} / 104^{\circ} 07^{\prime} \mathrm{E}$ & 2,109 \\
\hline & & & $35^{\circ} 30^{\prime} \mathrm{N} / 103^{\circ} 48^{\prime} \mathrm{E}$ & 2,244 \\
\hline & & & $35^{\circ} 33^{\prime} \mathrm{N} / 103^{\circ} 55^{\prime} \mathrm{E}$ & 2,160 \\
\hline & & & $35^{\circ} 59^{\prime} \mathrm{N} / 104^{\circ} 17^{\prime} \mathrm{E}$ & 2,204 \\
\hline & Longxi (LX) & LXA (6) & $34^{\circ} 53^{\prime} \mathrm{N} / 104^{\circ} 35^{\prime} \mathrm{E}$ & 2,019 \\
\hline & & & $34^{\circ} 53^{\prime} \mathrm{N} / 104^{\circ} 52^{\prime} \mathrm{E}$ & 2,142 \\
\hline & & & $34^{\circ} 52^{\prime} \mathrm{N} / 104^{\circ} 52^{\prime} \mathrm{E}$ & 2,031 \\
\hline \multirow[t]{8}{*}{ Gansu, spring } & Longxi (LX) & LXB (35) & $34^{\circ} 52^{\prime} \mathrm{N} / 104^{\circ} 52^{\prime} \mathrm{E}$ & 2,179 \\
\hline & & & $34^{\circ} 55^{\prime} \mathrm{N} / 104^{\circ} 51^{\prime} \mathrm{E}$ & 2,075 \\
\hline & Tongwei (TW) & TWB (5) & $35^{\circ} 14^{\prime} \mathrm{N} / 105^{\circ} 24^{\prime} \mathrm{E}$ & 2,114 \\
\hline & & & $35^{\circ} 17^{\prime} \mathrm{N} / 105^{\circ} 19^{\prime} \mathrm{E}$ & 1,910 \\
\hline & & & $35^{\circ} 09^{\prime} \mathrm{N} / 105^{\circ} 24^{\prime} \mathrm{E}$ & 1,976 \\
\hline & & & $35^{\circ} 11^{\prime} \mathrm{N} / 105^{\circ} 16^{\prime} \mathrm{E}$ & 1,750 \\
\hline & Kangle (KL) & KLB (1) & $35^{\circ} 20^{\prime} \mathrm{N} / 103^{\circ} 33^{\prime} \mathrm{E}$ & 2,160 \\
\hline & Gangu (GG) & GGB (2) & $34^{\circ} 48^{\prime} \mathrm{N} / 105^{\circ} 27^{\prime} \mathrm{E}$ & 1,838 \\
\hline
\end{tabular}

\footnotetext{
a Autumn: samples were collected from November to January; spring: samples were collected from April to June.
}

${ }^{\mathrm{b}}$ Samples were divided into subpopulations based on geographic locations where they were collected. 
For all isolates, 88 loci were recorded following the format of GENALEX 6.2 (17). There were 278 from 283 isolates used for further analysis. A principal coordinate plot based on Nei's distances between all pairs of AFLP genotypes was generated with GENALEX 6.2 and was used to generate a two-dimensional principal coordinate analysis (PCA) plot showing the distribution of genotypes among the studied populations. The percentages of genetic differentiation within and among populations were determined via the analysis of molecular variance (AMOVA) with 999 permutations. The parameter $\varphi p t$ (analogous to Fst for binary data) was used to determine the differentiation between any two subpopulations. If the observed $\varphi p t$ value differed significantly from zero, the null hypothesis of no genetic differentiation could be rejected. The significant difference between any two studied populations can be determined when $\varphi p t>0.25$ (8).

The effect of the Liupan Mountains on the genetic diversity of Ningxia populations was studied by analyzing the frequency of shared genotypes among the subpopulations to infer possible gene flow and the pathway among the studied subpopulations. To study the relationship of seasonal subpopulations between the two provinces, the isolates sampled from Gansu were grouped into autumn (GSA) and spring (GSB) subpopulations, while those from Ningxia were grouped into autumn (NXA), spring (NXB), and summer (NXC) subpopulations. The frequencies of shared AFLP genotypes among the seasonal subpopulations were analyzed. The migration rate $(R)$ between any two seasonal subpopulations was calculated by using the software Migrate-N (2) to infer the possible pathways among seasonal subpopulations. The $R$ was calculated as $R=\theta M$. The parameter estimated is $\theta=x N_{e} \mu$, where $x$ is an inheritance parameter, $N_{e}$ is effective population size, and $\mu$ is the mutation rate based on sequence data per site per generation. $M=m / \mu$, where $m$ is the migrant exchange rate per generation (2).

The possibilities of recombination of $P$. striiformis $\mathrm{f}$. sp. tritici were assessed using the method of the parsimony tree length permutation test (PTLPT) proposed by Burt et al. (3) with PAUP 4.0 (19). The length of the most parsimonious trees of the observed dataset for each population was compared with the distribution of the most parsimonious tree length estimated from 1,000 randomized datasets. According to Burt et al. (3), when the observed tree length of the sample is located within the distribution of the tree lengths of the randomized dataset (such as 1,000 permutations) at $P>0.05$, then the sample likely came from a recombined population. When it is located outside the distribution of the randomized dataset at $P<0.05$, then the sample likely came from a clonal population.

\section{Results}

Genotypic diversity. The AFLP with eight primer combinations generated 88 reliable polymorphic bands. From 107 isolates in Gansu Province, 55 AFLP genotypes were detected with genotypic diversity $(\mathrm{GD})=0.514$ (Table 3 ). From 176 isolates in Ningxia Province, 86 AFLP genotypes were detected with GD $=0.489$. In

Table 2. Primer combinations, their sequences and number of polymorphic bands obtained with amplified fragment length polymorphism for samples of Puccinia striiformis collected from Gansu and Ningxia Provinces of China in this study

\begin{tabular}{|c|c|c|c|}
\hline Primer combination & \multicolumn{2}{|c|}{ Sequence } & $\begin{array}{c}\text { Number of } \\
\text { polymorphic bands }\end{array}$ \\
\hline PstI-adapter & 5'-TGTACGCAGTCTAC-3' & 3'-ACGTACATGCGTCAGATGCTC-5' & $\ldots$ \\
\hline MseI-adapter & 5'-TACTCAGGACTCAT-3' & 3'-GAGTCCTGAGTAGCAG-5' & $\ldots$ \\
\hline \multirow[t]{2}{*}{ Mse I0/ Pst $\mathrm{I} 0$} & 5'-GACGATGAGTCCTGAGTAA-3' & 5'-GTAGACTGCGTACATGCAG-3' & $\ldots$ \\
\hline & Labeled $^{\mathrm{a}}$ & Coupled with primer & \\
\hline M12/P14 & 5'-FAMGACGATGAGTCCTGAGTAAAC-3' & 5'-GTAGACTGCGTACATGCAGAT-3' & 14 \\
\hline M15/P16 & 5'-FAMGACGATGAGTCCTGAGTAACA-3' & 5'-GTAGACTGCGTACATGCAGCC-3' & 10 \\
\hline M26/P12 & 5'-FAMGACGATGAGTCCTGAGTAATT- $3^{\prime}$ & 5'-GTAGACTGCGTACATGCAGAC-3' & 15 \\
\hline M12/P11 & 5'-FAMGACGATGAGTCCTGAGTAAAC-3' & 5'-GTAGACTGCGTACATGCAGAA-3' & 6 \\
\hline M16/P16 & 5'-HEXGACGATGAGTCCTGAGTAACC-3' & 5'-GTAGACTGCGTACATGCAGCC-3' & 12 \\
\hline M16/P12 & 5'-HEXGACGATGAGTCCTGAGTAACC-3' & 5'-GTAGACTGCGTACATGCAGAC-3' & 9 \\
\hline M25/P15 & 5'-HEXGACGATGAGTCCTGAGTAATG-3' & 5'-GTAGACTGCGTACATGCAGCA-3' & 8 \\
\hline $\mathrm{M} 17 / \mathrm{P} 22$ & 5'-HEXGACGATGAGTCCTGAGTAACG-3' & 5'-GTAGACTGCGTACATGCAGGT-3' & 14 \\
\hline
\end{tabular}

a Primers' sequences were labeled with FAM and HEX fluorescence.

Table 3. Amplified fragment length polymorphism genotypes and within-population genetic diversities of Puccinia striiformis obtained from different counties in Gansu and Ningxia provinces, China ${ }^{\mathrm{a}}$

\begin{tabular}{|c|c|c|c|c|c|}
\hline Province, county & $\begin{array}{l}\text { Number of isolates sampled } \\
\text { in each county }\end{array}$ & $\begin{array}{l}\text { Number of genotypes } \\
\text { (genotypic diversity) }\end{array}$ & Subpopulations $^{\text {b }}$ & I & $\mathbf{H}$ \\
\hline \multicolumn{6}{|l|}{ Gansu } \\
\hline Zhuanglang & 8 & $6(0.750)$ & ZLA & $0.474 \pm 0.212$ & $0.3164 \pm 0.159$ \\
\hline \multirow[t]{2}{*}{ Tongwei } & 15 & $13(0.867)$ & TWA & $0.446 \pm 0.243$ & $0.2991 \pm 0.181$ \\
\hline & & & TWB & $0.423 \pm 0.278$ & $0.2891 \pm 0.195$ \\
\hline Gangu & 33 & $25(0.758)$ & GGA & $0.553 \pm 0.133$ & $0.3727 \pm 0.114$ \\
\hline Kangle & 10 & $9(0.900)$ & KLA & $0.534 \pm 0.188$ & $0.3636 \pm 0.144$ \\
\hline \multirow{2}{*}{ Longxi } & 41 & $25(0.610)$ & LXA & $0.372 \pm 0.276$ & $0.2494 \pm 0.192$ \\
\hline & & & LXB & $0.536 \pm 0.173$ & $0.3630 \pm 0.136$ \\
\hline Subtotal & 107 & $55(0.514)$ & Combined & $0.583 \pm 0.127$ & $0.3994 \pm 0.109$ \\
\hline \multirow[t]{2}{*}{ Jingyuan } & 39 & $34(0.872)$ & JYB & $0.558 \pm 0.146$ & $0.3791 \pm 0.121$ \\
\hline & & & JYC & $0.555 \pm 0.141$ & $0.3762 \pm 0.113$ \\
\hline \multicolumn{6}{|l|}{ Ningxia } \\
\hline \multirow[t]{3}{*}{ Guyuan } & 109 & $66(0.605)$ & GYA & $0.483 \pm 0.144$ & $0.3127 \pm 0.118$ \\
\hline & & & GYB & $0.556 \pm 0.135$ & $0.3762 \pm 0.113$ \\
\hline & & & GYC & $0.463 \pm 0.188$ & $0.3017 \pm 0.149$ \\
\hline Xiji & 19 & $17(0.895)$ & $\mathrm{XJC}$ & $0.269 \pm 0.161$ & $0.3416 \pm 0.257$ \\
\hline Pengyang & 9 & $9(1.000)$ & PYA & $0.342 \pm 0.256$ & $0.2226 \pm 0.175$ \\
\hline Subtotal & 176 & $86(0.489)$ & Combined & $0.543 \pm 0.107$ & $0.3620 \pm 0.093$ \\
\hline
\end{tabular}

a Two genetic diversity indices were applied to analyze each geographic subpopulation: I = Shannon's information index and H = Nei's diversity index; mean \pm standard error.

b Subpopulations were classified as follows: Zhuanglang (ZL), Tongwei (TW), Gangu (GG), Kangle (KL), Longxi (LX), Jingyuan (JY), Guyuan (GY), Xiji $(\mathrm{XJ})$, and Pengyang (PY) counties; Combined = combined average; and autumn (A), spring (B), and summer (C). 
the Gansu population, the frequencies of 13 AFLP genotypes (ZLA1, ZLA4, ZLA6, TWA4, GGA1, GGA9, GGA14, GGA19, KLA1, KLA4, KLA5, LXB7, and LXB10) were 0.01 to 0.03 , while those of other genotypes were $<0.01$ (Fig. 2). In the Ningxia population, the frequencies of 23 AFLP genotypes were 0.01 to 0.03 , while those of the other 63 genotypes were $<0.01$. Importantly, 40 AFLP genotypes were shared by the two provinces, with the corresponding genotypic frequencies of 0.00 to 0.025 . However, two AFLP genotypes, GGA9 and GGA14, with the highest frequency (0.025) detected in the Gansu population, were not detected in the Ningxia population. Moreover, LXB10 had the highest frequency in the Ningxia population (0.025) but a lower frequency (0.011) in the Gansu population.

Genetic diversity. There was a consistent trend of genetic diversity among the 14 populations based on different parameters (Shannon's information index and Nei's index) (Table 3). Populations were classified as follows: Jingyuan (JY), Guyuan (GY), Gangu (GG), Kangle (KL), Longxi (LX), Zhuanglang (ZL), Tongwei (TW), Xiji (XJ), and Pengyang (PY) counties, and autumn (A), spring (B), and summer (C). The order of the populations based on genetic diversity according to Nei's index was JYB $>$ GYB $>$ JYC $>$ GGA $>$ KLA $>$ LXB $>$ ZLA $>$ GYA $>$ GYC $>$ TWA $>$ TWB $>$ XJC $>$ LXA $>$ PYA, while that according to Shannon's index was JYB $>$ GYB $>$ JYC $>$ GGA $>$ LXB $>$ KLA $>$ GYA $>$ ZLA $>$ GYC $>$ TWA $>$ TWB $>$ XJC $>$ LXA $>$ PYA. The average $\mathrm{I}$ and $\mathrm{H}$ of the Gansu population $(0.583 \pm 0.127$ and 0.399 \pm 0.109 , respectively) were higher than those of the Ningxia population ( $0.543 \pm 0.107$ and $0.362 \pm 0.093$, respectively). According to Hartl and Clark (8), the value of genetic differentiation $\varphi p t>0.25$ implies a significant genetic difference between two populations. Thus, the subpopulations TWB versus
LXA, TWB versus GYA, TWB versus GYC, XJC versus LXA, XJC versus $\mathrm{LXB}, \mathrm{XJC}$ versus TWB, and PYA versus TWB were genetically different at $P<0.05$ (Table 4). AMOVA revealed that $83 \%$ of molecular variation was attributed to the difference within populations $(P=0.001)$ and $13 \%$ to that among populations (data not shown). The PCA of the AFLP data (Fig. 3) showed that the horizontal and vertical coordinates represented 16.75 and $35.52 \%$ of the total genetic variance, respectively. Fourteen sampled populations were not clearly separated, except for XJC and TWB, which were mainly located in the first quartile and second quartile, respectively (Fig. 3).

Liupan Mountains and gene flow. In all, 87 isolates sampled from volunteer seedlings in Ningxia Province were divided into three groups according to the counties where samples were collected: JY + GY, PY, and XJ. Fifty-three AFLP genotypes were detected among the three groups. Seven genotypes were shared by $\mathrm{JY}+\mathrm{GY}$ and $\mathrm{XJ}$, two shared by $\mathrm{XJ}$ and PY, and six shared by $\mathrm{JY}+$ GY and PY. Only one genotype (GGA20) was shared by all three groups (Fig. 4). Furthermore, based on $\mathrm{Nm}$, the gene flow of $\mathrm{XJ} \leftrightarrow$ PY $(N m=11.20)$ was lower than the other two groups $(\mathrm{GY}+\mathrm{JY}$ $\leftrightarrow \mathrm{XJ}, N m=15.17$; and $\mathrm{GY}+\mathrm{JY} \leftrightarrow \mathrm{PY}, N m=14.95)$, probably due to blocking, to some degree, by the Liupan Mountains. Thus, the Liupan Mountains may limit gene flow and population exchange.

Seasonal populations. The molecular variance between spring and autumn populations in Gansu (13\%) was greater than in Ningxia $(6 \%)$. The distribution of AFLP genotypes indicated that 11 genotypes were shared by the GSA population and the NXA population (Fig. 5A), and Nei's genetic diversity of NXA $(0.481 \pm$ $0.004)$ was greater than that of GSA $(0.422 \pm 0.075)$. Among the GSB population and NXB populations, there were 10 common

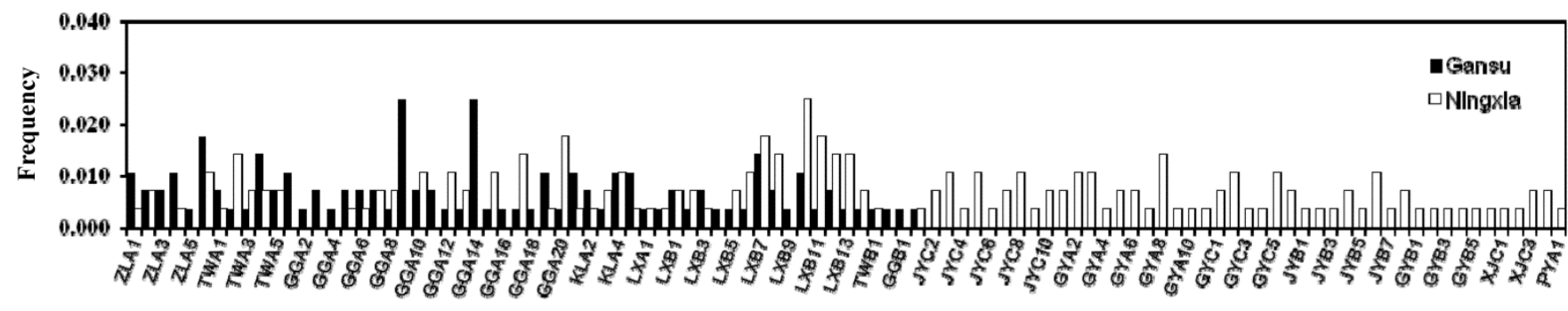

AFLP genotype of Puccinia striiformis

Fig. 2. Amplified fragment length polymorphism (AFLP) genotypes of Puccinia striiformis and the corresponding frequencies based on 283 isolates sampled from Gansu and Ningxia provinces. In all, 40 genotypes were shared between these two provinces.

Table 4. Pairwise matrix of Nei's genetic distance (below the diagonal) and $\varphi p t$ values (above the diagonal) for 14 subpopulations of Puccinia striiformis sampled from Gansu and Ningxia provinces of China ${ }^{\mathrm{a}}$

\begin{tabular}{|c|c|c|c|c|c|c|c|c|c|c|c|c|c|c|}
\hline \multirow[b]{2}{*}{ Subpopulation } & \multicolumn{7}{|c|}{ Gansu } & \multicolumn{7}{|c|}{ Ningxia } \\
\hline & ZLA & TWA & GGA & KLA & LXA & LXB & TWB & JYC & GYA & GYC & JYB & GYB & $\mathrm{XJC}$ & PYA \\
\hline \multicolumn{15}{|l|}{ Gansu } \\
\hline ZLA & & 0.056 & 0.051 & 0.118 & 0.191 & 0.192 & 0.245 & 0.142 & 0.188 & 0.226 & 0.157 & 0.125 & 0.234 & 0.222 \\
\hline TWA & 0.090 & $\ldots$ & 0.010 & 0.059 & 0.106 & 0.145 & 0.248 & 0.114 & 0.155 & 0.200 & 0.149 & 0.100 & 0.223 & 0.183 \\
\hline GGA & 0.079 & 0.042 & $\ldots$ & 0.018 & 0.069 & 0.096 & 0.170 & 0.053 & 0.111 & 0.165 & 0.064 & 0.063 & 0.192 & 0.141 \\
\hline KLA & 0.159 & 0.096 & 0.057 & $\ldots$ & 0.018 & 0.054 & 0.117 & 0.105 & 0.146 & 0.191 & 0.138 & 0.108 & 0.216 & 0.170 \\
\hline LXA & 0.196 & 0.117 & 0.095 & 0.084 & & 0.169 & $0.293 *$ & 0.115 & 0.163 & 0.202 & 0.109 & 0.105 & $0.261^{*}$ & 0.202 \\
\hline LXB & 0.194 & 0.136 & 0.085 & 0.079 & 0.168 & & 0.055 & 0.129 & 0.195 & 0.219 & 0.160 & 0.145 & $0.262 *$ & 0.239 \\
\hline TWB & 0.291 & 0.264 & 0.200 & 0.182 & 0.311 & 0.099 & $\ldots$ & 0.155 & $0.266^{*}$ & $0.300^{*}$ & 0.174 & 0.164 & $0.368^{*}$ & $0.355 *$ \\
\hline \multicolumn{15}{|l|}{ Ningxia } \\
\hline JYC & 0.159 & 0.116 & 0.099 & 0.085 & 0.131 & 0.115 & 0.193 & & 0.018 & 0.052 & 0.067 & 0.039 & 0.074 & 0.047 \\
\hline GYA & 0.155 & 0.119 & 0.106 & 0.098 & 0.134 & 0.146 & 0.246 & 0.028 & & 0.028 & 0.131 & 0.064 & 0.039 & 0.010 \\
\hline GYC & 0.176 & 0.140 & 0.135 & 0.127 & 0.149 & 0.158 & 0.265 & 0.044 & 0.023 & & 0.172 & 0.105 & 0.042 & 0.050 \\
\hline JYB & 0.206 & 0.173 & 0.148 & 0.111 & 0.151 & 0.156 & 0.240 & 0.094 & 0.125 & 0.146 & & 0.009 & 0.116 & 0.083 \\
\hline GYB & 0.140 & 0.103 & 0.092 & 0.082 & 0.122 & 0.119 & 0.197 & 0.039 & 0.043 & 0.060 & 0.062 & 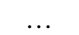 & 0.037 & 0.175 \\
\hline XJC & 0.177 & 0.155 & 0.164 & 0.150 & 0.188 & 0.208 & $0.335^{* *}$ & 0.063 & 0.034 & 0.036 & 0.158 & 0.080 & & 0.155 \\
\hline PYA & 0.185 & 0.141 & 0.145 & 0.136 & 0.151 & 0.203 & 0.329 & 0.071 & 0.039 & 0.057 & 0.180 & 0.085 & 0.040 & $\ldots$ \\
\hline
\end{tabular}

${ }^{a}$ Bold, italics, and asterisks: * indicates $\varphi p t>0.25$, significant genetic differentiation existed between the pair-wise subpopulations, and $* *$ indicates the largest genetic distance (GD) between the pairwise populations. Subpopulations were classified as follows: Zhuanglang (ZL), Tongwei (TW), Gangu (GG), Kangle (KL), Longxi (LX), Jingyuan (JY), Guyuan (GY), Xiji (XJ), and Pengyang (PY) counties; and autumn (A), spring (B), and summer (C). 
genotypes, 8 of which had higher frequencies in GSB than in NXB (Fig. 5B). The genetic diversity of GSB $(0.427 \pm 0.077)$ was greater than that of NXB $(0.412 \pm 0.096)$. Thus, there might be gene flow between GSA and NXA and between GSB and NXB. Furthermore, 12 genotypes were shared between GSA and NXB (Fig. 5C) and 7 shared between NXA and NXB (Fig. 5D). The migration rates $(R)$ between GSA and NXA (Fig. 5A), between GSB and NXB (Fig. 5B), between GSA and NXB (Fig. 5C), and between NXA and NXB (Fig. 5D) were 0.50, 1.21, 0.70, and 0.92, respectively. These results indicate a certain degree of exchange or gene flow among these populations.

Test for reproductive mode. Of the seven subpopulations of Gansu Province, two (ZLA and LXA) showed that the observed most-parsimonious tree lengths were located inside the distributions of the 1,000 randomized tree-length datasets (Fig. 6) at $P=$ 0.299 and 0.512 (Fig. 6), respectively, demonstrating the possibility of recombination. Others showed possibility of either clonal or mixtures of clonal with recombined subpopulations at $P<0.05$ (Fig. 6). Similarly, the possibility of recombination could be inferred in two of seven subpopulations in Ningxia Province at $P=$ 0.687 for XJC and $P=0.482$ for PYA (Fig. 6). Others showed a possibility of either clonal or mixtures of clonal and recombined subpopulations at $P<0.05$ (Fig. 6).

\section{Discussion}

Recent studies confirmed the high level of genetic diversity and possibility of recombination of $P$. striiformis f. sp. tritici populations in Gansu $(6,14)$. The present study indicated that genetic diversity was slightly higher in the Gansu population than in the Ningxia population. The existence of the 40 AFLP genotypes shared between the two provinces demonstrated frequent population exchanges. Furthermore, the data indicated population exchanges within the same season between the two provinces. The Liupan Mountains in Ningxia Province may not significantly obstruct population exchange between the two sides. The possibility of recombination in some subpopulations was inferred in both provinces.

Similar genotypic diversity was detected in the Ningxia (GD = $0.489)$ and Gansu $(\mathrm{GD}=0.514)$ populations. The parts of the two provinces where the samples were collected have similar ecological niches suitable for pathogen over-summering. They also have similar cropping systems but genetically differing wheat varieties, which facilitates the production of new $P$. striiformis $\mathrm{f}$. sp. tritici races. High genetic and genotypic diversities, as well as the large number of shared genotypes, imply probable and frequent ex- change of the populations and gene flow between these two regions. Previous epidemiological studies (11) proposed that these two regions could be considered as a joint area, providing oversummered inoculum and playing similar functions in nationwide epidemics. The present study provided phylogenetic evidence supporting this hypothesis. Thus, disease prediction, design of disease management strategies, and estimation of pathogen evolutionary trends could be made based on the combination of these two regions into one ecological zone.

The genotype distributions of three population groups from the western side of the Liupan Mountains (XJ), on the mountains (GY $+\mathrm{JY}$ ), and from the eastern side (PY) showed that $11.7 \%$ of genotypes (six genotypes) were shared between GY $+J Y$ and XJ and $11.3 \%$ of genotypes (five genotypes) were shared between GY +

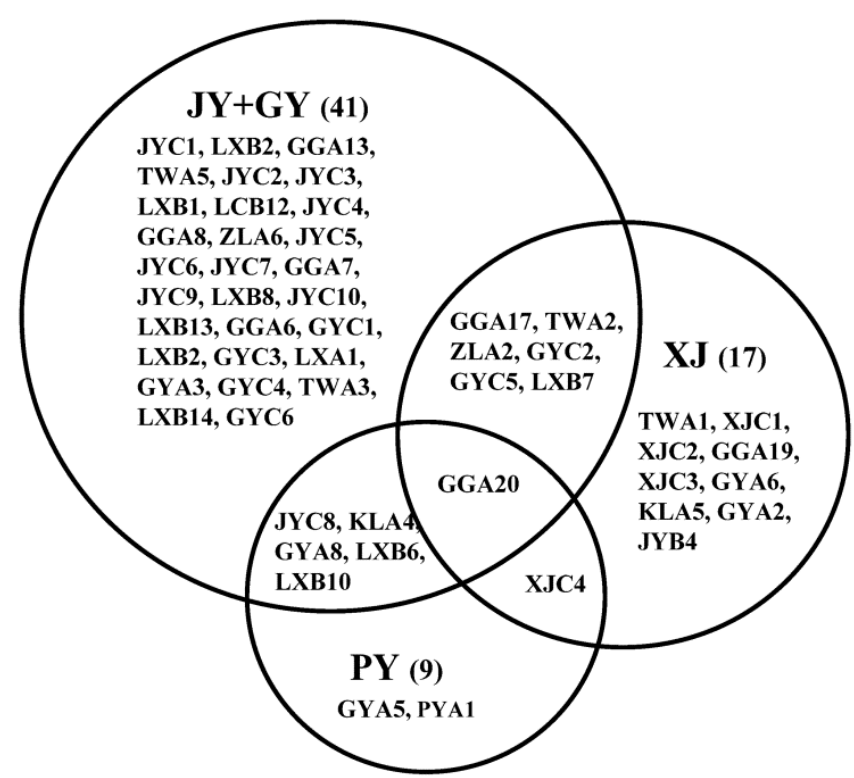

Fig. 4. Distributions of amplified fragment length polymorphism (AFLP) genotypes of Puccinia striiformis for three population groups in Ningxia Province. In total, 53 AFLP genotypes were detected. Seven genotypes were shared by JY $+G Y$ and $X J$, two were shared by $X J$ and $P Y$, and six were shared by JY + GY and PY. Only one genotype was shared by all three groups. Numbers in parentheses are the total number of AFLP genotypes. JY $+G Y$ is the combined population of Jingyuan (JY) and Guyuan (GY) Counties and PY and XJ are the Pengyang and Xiji subpopulations, respectively.

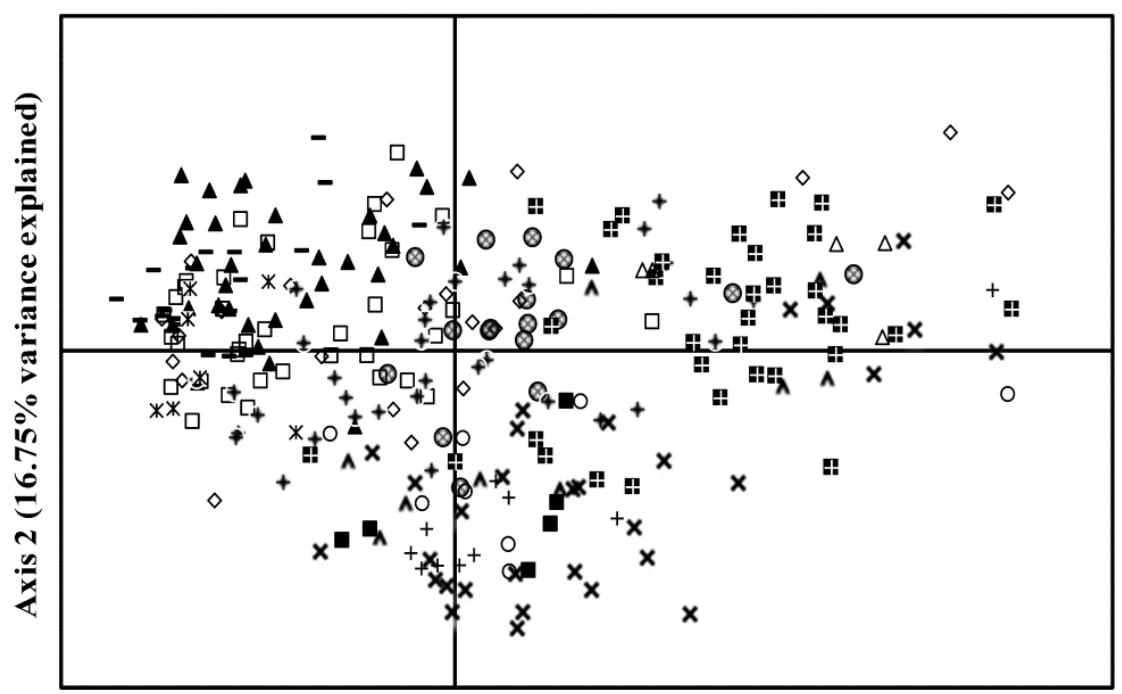

Aixs 1 (35.52\% variance explained) $\diamond$ Jingyuan (summer)

$\square$ Guyuan (autumn)

^ Guyuan (summer)

๑ Jingyuan (spring)

+ Guyuan (spring)

- Xiji (summer)

* Pengyang (summer)

$\circ$ Zhuanglang (autumn)

+ Tongwei (autumn)

× Gangu (autumn)

^ Kangle (autumn)

- Longxi (autumn)

* Longxi (spring)

$\Delta$ Tongwei (spring)

Fig. 3. Results of the principal coordinates analysis on 14 Puccinia striiformis subpopulations sampled from Gansu and Ningxia provinces in China. 
JY and PY. All isolates were sampled at about 2,000 m asl, and population exchange from both sides of the mountains was indicated. This agrees with the previous conclusion demonstrating that, because the wind direction was variable, the spores of $P$. striiformis f. sp. tritici could disperse in various directions following airflow at $<3,000 \mathrm{~m}$ asl (24). However, only two genotypes (GGA20 and XJC4) were shared by PY and XJ on both sides of the mountains and only one genotype (GGA20) was shared by all three studied population groups. Thus, there sometimes may be significant limiting effects of the Liupan Mountains on gene flow and population exchange.

There were indications of gene flow in autumn and spring populations between Ningxia and Gansu Provinces. Genotypic frequencies indicated gene flow in autumn mostly from Ningxia to Gansu whereas, in spring. this was from Gansu to Ningxia (Fig. 5A and B). In China, north winds prevail in autumn and P. striiformis f. sp. tritici spores disperse from Ningxia to Gansu (Fig. 1). However, in spring, southern prevailing winds carry the spores from Gansu to Ningxia. Seven AFLP genotypes were shared between the autumn population in Ningxia (NXA) and the spring population in Ningxia (NXB) (Fig. 5D). This suggests that, after dispersal from Gansu in autumn, the Ningxia population can over-winter locally (e.g., in Pengyang; 26). Whether P. striiformis f. sp. tritici in other regions of Ningxia Province could over-winter remains to be determined.

Phylogenetic analysis provides a tool to infer the reproductive mode and the possibility of recombination in the studied populations. The existence of recombination in the Gansu populations has been confirmed by different studies $(6,13)$. The present study confirmed this feature in Ningxia. In fact, the applicability of the PTLPT method to infer the existence of recombination in $P$. striiformis $\mathrm{f}$. sp. tritici populations was confirmed by studies determining the existence of recombined populations in Gansu Province and clonal populations in Yunnan Province (13). All these studies provided useful information on $P$. striiformis $\mathrm{f}$. $\mathrm{sp}$. tritici population structures in different geographical regions of China to help determine the locations where attention to population dynamics relating to origination of new races should be directed. Moreover, Jin et al. (9) reported that Berberis chinensis was likely an alternative host of $P$. striiformis f. sp. tritici. Zhao et al. (30) found Berberis spp. in three provinces of China. Due to the similar geographic and topographic features in Gansu and Ningxia, the pathogen can both over-summer and over-winter in the same locations, which may result in the continuation of the pathogen life cycle easily and locally. Thus, the new mutant genotypes can survive and reproduce more easily than in other regions where the pathogen cannot both over-summer and over-winter in the same location.

For some locations such as TW and LX, recombination was likely in autumn but less likely in spring for the samples collected from the same locations. It is possible that the spores in the autumn population mainly came from volunteer wheat and late-maturing wheat after over-summering, where the recombination likely occurred. Thus, the possibility of recombination could be relatively high. However, the spring populations most likely were those that over-wintered locally without long-distance spore dispersal and genetic exchange. Thus, the possibility of recombination could be relatively low. Therefore, spring populations such as TWB and LXB should probably be considered clonal or mixed populations.

The information obtained from this study will be useful in estimating the dynamics of pathogen populations and interregional disease epidemics. Because the spores could disperse from Ningxia to Gansu in the autumn and from Gansu to Ningxia in the spring, the effects of population exchange between the two provinces on stripe rust epidemics should be intensively studied. The information from the present study on the effects of the Liupan Mountains on changes in P. striiformis f. sp. tritici population structures should be considered as preliminary.

It was reported (26) that the pathogen was able to over-winter in Pengyang of Ningxia Province. Furthermore, the present study confirmed possible recombination in PYA. We also inferred that gene flow in autumn was likely from Ningxia to Gansu. Because southern Ningxia sometimes has over-wintered inoculum, it may play a role in frequently providing inoculum to local wheat and less frequently to other areas. Importantly, determination of the

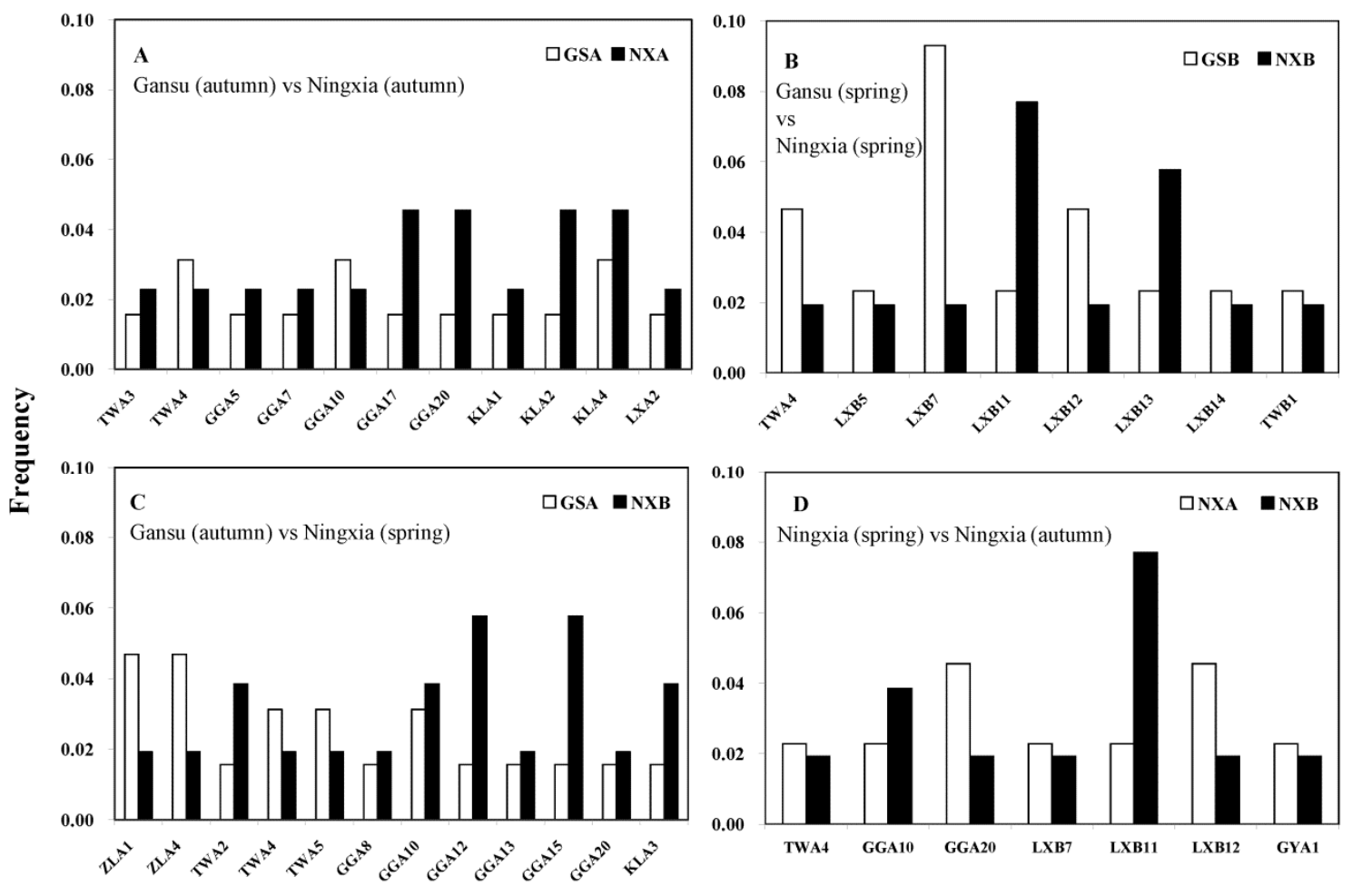

Shared AFLP genotype of Puccinia striiformis

Fig. 5. Comparison of frequencies of the amplified fragment length polymorphism genotypes shared by seasonal Puccinia striiformis subpopulations in Gansu (GS) and Ningxia (NX) provinces in China. Isolates were sampled in spring (B) and autumn (A) in each province. 
possibility of the pathogen over-wintering in more locations of Ningxia Province could provide information necessary to estimate initial spring inoculum potential and to monitor the nationwide epidemics of stripe rust and pathogen population dynamics in other regions of China.
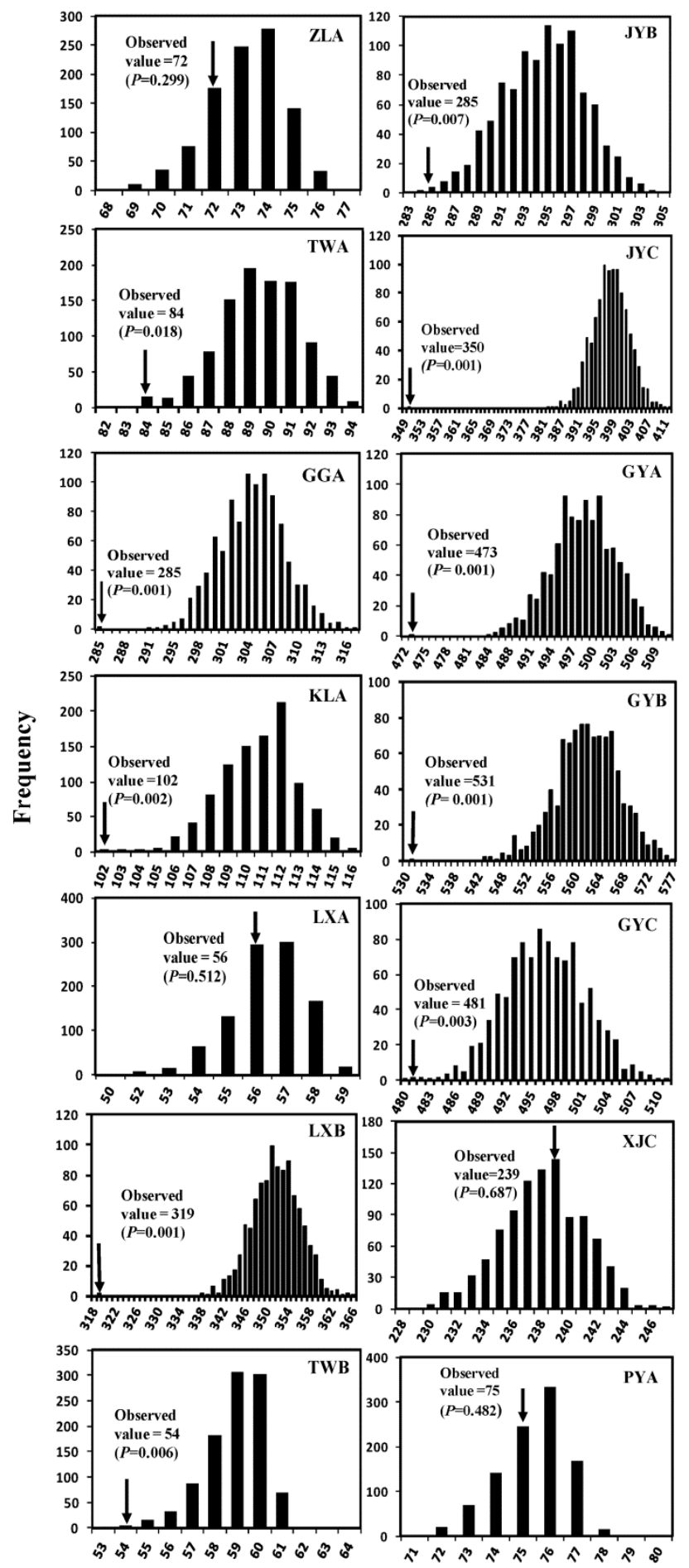

Tree length

Fig. 6. Observed values (arrows) of the most parsimonious tree length of amplified fragment length polymorphism genotypes of Puccinia striiformis estimated for 14 subpopulations in the provinces of Gansu (7 figures on the left) and Ningxia (7 figures on the right) in relation to the distribution of randomized datasets of tree length from 1,000 permutations using parsimony tree length permutation test method. Values with an arrow located inside the distribution imply the possibility at $P>0.05$ that the samples were from a recombined population, while values with an arrow located away from the distribution implies the possibility at $P<0.05$ that the samples were from a clonal population (3).
The $P$. striiformis f. sp. tritici populations in China showed complex evolution of virulence $(4,22)$, demonstrating a unique virulence spectrum system (25) that differs from other parts of the world. Chen et al. (4) summarized the historical evolution of virulence development, and provided clues about the genetics of new race development. They demonstrated that the occurrence of new races in China was likely due to single-gene mutations to virulence against particular host resistance genes. For instance, race CY29 evolved to race CY30 due to a mutation to virulence against the $Y r 3 b$ and $Y r 4 b$ genes of host Hybrid 46. This race also evolved to S11-7 through mutation to virulence against the $\mathrm{YrSu}$ gene of the resistant host Suwon 11 (4). Because the northwestern mountainous areas of China were the main region for pathogen over-summering and the originating area of new races, information on genetic structure and virulence development of pathogen populations is important to understand the evolutionary mechanism of the stripe rust fungus. This study showed high genetic and genotypic diversities in both Gansu and Ningxia Provinces with an AFLP approach, providing the molecular evidence of the complexity of pathogen population structure in the over-summering regions. In addition to gene mutation as a result of pathogen adaptation to host resistance, parasexuality or somatic recombination is considered to be as an alternative way to initiate new races (4). Molecular evidence in the present study confirmed that a recombination process likely occurred in at least some local populations in both Gansu and Ningxia Provinces. However, no clear relationship has yet been found between the virulence spectrum of pathotypes and the DNA polymorphism pattern of genotypes (5). Thus, the possibility of using AFLP markers to reveal the virulence spectrum has been inadequately studied. Some studies reported correspondence of SSR genotypes with pathotypes for $P$. triticina under strong host selection (7). We are engaged in a similar study to find the possible relationships between AFLP genotypes and virulence patterns.

\section{Acknowledgments}

This work was supported by The National Basic Research Program of China (No. 2013CB127700) and Specialized Research Fund for the Doctoral Program of Higher Education of China. We thank N. Q. Yang (Ningxia Agricultural Technology Extension Station [NATES]), H. Li (Gansu Plant Protection Station [GPPS]), and the following county stations for their assistance in sample collection: Jingyuan, Guyuan, Xiji, and Pengyang under NATES and Zhuanglang, Tongwei, Longxi, Gangu, and Kangle under GPPS; Y. Li and W.-F. Leng for their assistance in sample processing and pathogen reproduction; and D. Morgan, University of California, Kearney Agricultural Center, for comments on this manuscript prior to submission and in revision.

\section{Literature Cited}

1. Agapow, P. M., and Burt, A. 2001. Indices of multilocus linkage disequilibrium. Mol. Ecol. Notes. 1:101-102.

2. Beerli P. 2004. Migrate: Documentation and program. Part of LAMARC, version 2.4.4. http://evolution.gs.washington.edu/lamarc/index.html

3. Burt, A., Carter, D. A., Koenig, G. L., White, T. J., and Taylor, J. W. 1996 Molecular markers reveal cryptic sex in the human pathogen Coccidioides immitis. Proc. Natl. Acad. Sci. USA 93:770-773.

4. Chen, W. Q., Wu, L. R., Liu, T. G., Xu, S. C., Jin, S. L., Peng, Y. L., and Wang, B. T. 2009. Race dynamics, diversity, and virulence evolution in Puccinia striiformis f. sp. tritici, the causal agent of wheat stripe rust in China from 2003 to 2007. Plant Dis. 93:1093-1101.

5. Chen, X., Line, R. F., and Leung, H. 1993. Relationship between virulence variation and DNA polymorphism in Puccinia striiformis. Phytopathology 83:1489-1497.

6. Duan, X., Tellier, A., Wan, A., Leconte, M., de Vallavieille-Pope, C., and Enjalbert, J. 2010. Puccinia striiformis f. sp. tritici presents high diversity and recombination in the over-summering zone of Gansu, China. Mycologia 102:44-53.

7. Goyeau, H., Halkett, F., Zapater, M. F., Carlier, J., and Lannou, C. 2007. Clonality and host selection in the wheat pathogenic fungus Puccinia triticina. Fungal Genet. Biol. 44:474-483.

8. Hartl, D. L., and Clark, A. G. 1998. Principles of Population Genetics. Sinauer Associates, Sunderland, MA.

9. Jin, Y., Szabo, L. J., and Carson, M. 2010. Century-old mystery of Puccinia striiformis life history solved with the identification of Berberis as an alternate host. Phytopathology 100:432-435.

10. Justesen, A. F., Ridout, C. J., and Hovmøller, M. S. 2002. The recent history of Puccinia striiformis f. sp. tritici in Denmark as revealed by disease incidence and AFLP markers. Plant Pathol. 51:13-23.

11. Li, Z. Q., and Zeng, S. M. 2000. Wheat Rusts in China. China Agricultural 
Press, Beijing.

12. Line, R. F. 2002. Stripe rust of wheat and barley in north America: a retrospective historical review. Annu. Rev. Phytopathol. 40:75-118.

13. Liu, X. F., Huang, C., Sun, Z. Y., Liang, J. M., Luo, Y., and Ma, Z. H. 2011. Analysis of population structure of Puccinia striiformis in Yunnan Province of China by using AFLP. Eur. J. Plant Pathol. 129:43-55.

14. Lu, N. H., Wang, J. F., Chen, X. M., Zhan, G. M., Chen, C. Q., Huang, L. L., and Kang, Z. S. 2011. Spatial genetic diversity and interregional spread of Puccinia striiformis f. sp. tritici in Northwest China. Eur. J. Plant Pathol. 131:685-693.

15. Mboup, M., Leconte, M., Gautier, A., Wan, A. M., Chen, W., de Vallavieille-Pope, C., and Enjalbert, J. 2009. Evidence of genetic recombination in wheat yellow rust populations of a Chinese oversummering area. Fungal Genet. Biol. 46:299-307.

16. Nei, M. 1972. Genetic distance between populations. Am. Nat. 106:283292.

17. Peakall, R., and Smouse, P. E. 2006. GENALEX 6: genetic analysis in Excel. Population genetic software for teaching and research. Mol. Ecol. Notes 6:288-295.

18. Slatkin, M., and Barton, N. H. 1989. A comparison of three indirect methods for estimating average levels of gene flow. Evolution 43:1349-1368.

19. Swofford, D. L. 1998. PAUP: Phylogenetic Analysis Using Parsimony (and other methods). Sinauer Associates, Sunderland, MA.

20. Viljanen-Rollinson, S. L. H., and Cromey, M. G. 2002. Pathways of entry and spread of rust pathogens: implications for New Zealand's biosecurity. N. Z. Plant Prot. 55:42-48

21. Wan, A. M., Chen, X. M., and He, Z. H. 2007. Wheat stripe rust in China. Aust. J. Agric. Res. 58:605-619.

22. Wan, A. M., Zhao, Z. H., Chen, X. M., He, Z. H., Jin, S. L., Jia, Q. Z., Yao,
G., Yang, J. X., Wang, B. T., Li, G. B., Bi, Y. Q., and Yuan, Z. Y. 2004 Wheat stripe rust epidemic and virulence of Puccinia striiformis f. sp. tritici in China in 2002. Plant Dis. 88:896-904.

23. Wang, J. F., Chen, C. Q., Lu, N. H., Peng, Y. N., Zhan, G. M., Huang, L. L., and Kang, Z. S. 2010. SSR analysis of population genetic diversity of Puccinia striiformis f. sp. tritici in Sichuan Province, China. Mycosystema 29:206-213.

24. Xie, S. X., Wang, K. N., Chen, Y. L., and Chen, W. Q. 1993. Preliminary studies on the relationship between transport of wheat stripe rust and the upper air current in China. Acta Phytopathol. Sin. 23:203-209.

25. Yang, H. A., and Wu, L. R. 1990. Virulence gene and pathogenicity analysis of races of Puccinia Striiformis in China. Acta Phytopathol. Sin. 20:213217.

26. Yang, N. Q., Xie, C. J., Yang, M. J., Gao, H., Li, X., and Liu, Y. 2007. Epidemics and integrated protection countermeasure of Puccinia striiformis $\mathrm{f}$ sp. tritici in Ningxia Province, China. Ningxia Agric. For. Sci. Technol. 50:162-163.

27. Yeh, F. C., Yang, R. C., Boyle, T. B. J., Ye, Z. H., and Mao, J. X. 1997. POPGENE, the User-Friendly Shareware for Population Genetic Analysis. Molecular Biology and Biotechnology Centre, University of Alberta, Canada.

28. Zadoks, J. C. 1961. Yellow rust on wheat, studies in epidemiology and physiologic specialization. Tijdschr. Plantenziekten 67:69-256.

29. Zeng, S. M., and Luo, Y. 2006. Long-distance spread and interregional epidemics of wheat stripe rust in China. Plant Dis. 90:980-988.

30. Zhao, J., Zhang, H. C., Yao, J. N., Chen, X. M., and Kang, Z. S. 2011 Identification of Berberis spp. as alternate hosts of Puccinia striiformis $\mathrm{f}$. sp. tritici in China. Page 167 in: Borlaug Global Rust Initiative 2011 Technical Workshop. R. McIntosh, ed. St. Paul, MN. 